\title{
Dose-Dependent Prevention of Fibrosis in Aorta of Salt-Loaded Stroke-Prone Spontaneously Hypertensive Rats by Combined Delapril and Indapamide Treatment
}

\author{
Miranda Baccarani Contri, Francesca Taparelli, Monica Miselli, Giada Pedrazzi, \\ Barbara Bacchelli, and *†Giuseppe Biagini \\ Department of Biomedical Sciences, Sections of General Pathology and *Physiology, and $†$ Center of Clinical \\ Nutrition and Metabolic Diseases, University of Modena and Reggio Emilia, Modena, Italy
}

\begin{abstract}
Summary: Combined treatment with the angiotensin-converting enzyme (ACE) inhibitor delapril and the diuretic indapamide prevented vascular damage in vital organs of salt-loaded stroke-prone spontaneously hypertensive rats (SHRsp). Whether the changes occurring after long-term hypertension could also be modulated in large arteries was investigated. Two-month-old SHRsp were salt loaded and treated with the drug regimen until they reached $50 \%$ mortality or around midlife. In a first experiment, delapril $(12 \mathrm{mg} / \mathrm{kg})$ and indapamide $(1 \mathrm{mg} / \mathrm{kg})$ were administered daily separately or in combination. In the second dose-finding experiment, delapril $(6,3,1.5 \mathrm{mg} / \mathrm{kg})$ and indapamide $(0.5,0.25,0.125 \mathrm{mg} / \mathrm{kg})$ in decreasing dose combinations were analyzed. Ultrastructural, histomorphometric, and biochemical studies were performed on the thoracic aorta. When compared with delapril $(12 \mathrm{mg} / \mathrm{kg})$ or indapamide $(1 \mathrm{mg} / \mathrm{kg})$ administered individually for 5 months, the combination $12+1 \mathrm{mg} / \mathrm{kg}$ was able to prevent the increase in extracellular matrix deposition observed in other treatment groups, as assessed by histomorphometry or 4-OH-proline biochemical determination. In the second experiment, a half-dose (delapril $6 \mathrm{mg} / \mathrm{kg}$ + indapamide $0.5 \mathrm{mg} / \mathrm{kg}$ ) combination was similarly effective in counteracting fibrosis, but the other doses progressively failed. In the first experiment, the combination had a stabilizing effect on hypertension and stimulated diuresis. In the second experiment, arterial blood pressure values and sodium balance were not consistently affected by the treatments that antagonized fibrosis (i.e., delapril $6 \mathrm{mg} / \mathrm{kg}+$ indapamide 0.5 $\mathrm{mg} / \mathrm{kg}$ and, less efficiently, delapril $3 \mathrm{mg} / \mathrm{kg}+$ indapamide $0.25 \mathrm{mg} / \mathrm{kg}$ ). These results suggest that indapamide interacts with ACE inhibitors to limit aortic fibrosis independent of any well-established mechanism. Key Words: Angiotensin-converting enzyme inhibitors-Arteries-Diuretic agentsFibrosis-Hypertension-Stroke-prone spontaneously hypertensive rats.
\end{abstract}

Received July 27, 2001; accepted February 21, 2002.

Correspondence and reprint requests to Dr. Giuseppe Biagini at the Dipartimento di Scienze Biomediche, Sezione di Fisiologia, Università di Modena e Reggio Emilia, Via Campi, 287, 41100 Modena, Italy. E-mail: gbiagini@unimore.it
This work has been jointly funded by the University of Modena and Reggio Emilia (Applied Research Grant 1997-1998 and Progetto Giovani Ricercatori 2001-2202) and Chiesi Farmaceutici S.p.A. (Parma, Italy). 
An important goal of anti-hypertensive therapy is the preservation of arterial structural integrity (1). It is well known that large arteries undergo extensive remodeling during long-term hypertension, mainly consisting of vessel wall thickening due to fibrosis. This process is thought to result from the complex interaction between endothelial cells, leukocytes, and smooth muscle cells (2-4). In particular, arterial smooth muscle cells undergo hypertrophy and increase their metabolic activity assuming a "secretory phenotype." Some of these structural changes seem to be maintained even after reversal of the hypertensive state, leading to the permanent alteration of vessel wall architecture (5).

Drug treatments capable of lowering blood pressure levels have been shown to antagonize the effects of hypertension on large vessels (6). Generally, this result depends on the efficiency of the anti-hypertensive treatment in lowering blood pressure (1). Conversely, complete normalization of blood pressure is infrequent in medical practice (7), and even when hypertension is well controlled the associated arterial changes are not fully prevented or reversed $(8,9)$. As an exception, angiotensin-converting enzyme (ACE) inhibitors have been proposed to prevent fibrosis in the arterial wall independent of the efficiency of blood pressure control (3). This effect seems to result from the prevention of angiotensin II synthesis in the vessel wall, whereby angiotensin II can enhance endothelial permeability to plasma proteins, neutrophil migration, smooth muscle cell growth, and consequently extracellular matrix deposition (4).

Another factor recently addressed as putatively involved in arterial wall fibrosis and damage is sodium chloride intake. It is a classic although still disputed notion that sodium chloride intake can alter blood pressure leading to hypertension (10). However, several lines of evidence suggest that sodium chloride may damage the arterial wall directly apart from changes in blood pressure (11). Such evidence is more straightforward in animal models, especially stroke-prone spontaneously hypertensive rats (SHRsp), in which a high-sodium diet was found to increase arterial wall thickness and collagen deposition. Moreover, sodium chloride can negatively influence the properties of anti-hypertensive treatments, an effect that should be carefully evaluated in monotherapies with thiazide diuretics or ACE inhibitors $(12,13)$.

We recently demonstrated that the thiazidelike diuretic indapamide combined with the ACE inhibitor delapril consistently extends lifespan, preserves renal functions, and prevents heart hypertrophy without lowering arterial blood pressure, increasing diuresis in salt-loaded SHRsp $(14,15)$. In a third experiment $(16)$, we demonstrated that saluresis induced by combined treatment did not justify the protective effects found in salt-loaded SHRsp. Based on our previous findings, we hypothesized that the protective effects of delapril + indapamide could be extended to the vessel wall of large arteries, independent of the anti-hypertensive and diuretic effects of the combined treatment. To this aim, we studied the thoracic aorta of salt-loaded SHRsp with histomorphometric, ultrastructural, and biochemical techniques to determine the changes in smooth muscle cells, elastic laminae, and other extracellular matrix components, such as collagens and proteoglycans, consequent to different indapamide and delapril drug treatments.

\section{METHODS}

\section{Animals and treatments}

Male specific-pathogen-free SHRsp, 5-6 weeks old, were purchased from Charles River Italia (Calco, Italy). They were housed, two per cage, under controlled temperature $\left(23 \pm 1^{\circ} \mathrm{C}\right)$, humidity (about $\left.60 \%\right)$, and daylight cycle (light from 7 AM to $7 \mathrm{PM}$ ). After 2-3 weeks, they were fed a Japanese-similar sodium chloride-enriched diet (Mucedola, Settimo Milanese, Italy) characterized by high sodium $(0.36 \% \mathrm{wt} / \mathrm{wt})$ and low potassium $(0.72 \%)$ content and also lower protein amount (18\%) (17). A $1 \%$ sodium chloride solution replaced tap water as their beverage. Two different experiments were designed. In experiment 1 , the effects of delapril 12 $\mathrm{mg} / \mathrm{kg} / \mathrm{d}(\mathrm{n}=12)$ and indapamide $1 \mathrm{mg} / \mathrm{kg} / \mathrm{d}(\mathrm{n}=12)$ administered separately were compared with those of their combination $(\mathrm{n}=12)$. Drug-free salt-loaded rats were also considered to evaluate diet-related effects (n $=17$ ). In experiment 2 , the minimal effective doses of the combination able to counteract aortic remodeling in salt-loaded SHRsp were determined by using three different groups of treatment: delapril $6 \mathrm{mg} / \mathrm{kg} / \mathrm{d}+$ indapamide $0.5 \mathrm{mg} / \mathrm{kg} / \mathrm{d}(\mathrm{n}=10)$, delapril $3 \mathrm{mg} / \mathrm{kg} / \mathrm{d}+$ indapamide $0.25 \mathrm{mg} / \mathrm{kg} / \mathrm{d}(\mathrm{n}=10)$, delapril $1.5 \mathrm{mg} / \mathrm{kg} / \mathrm{d}+$ indapamide $0.125 \mathrm{mg} / \mathrm{kg} / \mathrm{d}(\mathrm{n}=10)$. Drug-free and saltloaded SHRsp $(n=10)$ were also included in the second experiment. In each experiment, drugs were dissolved within the beverage ( $1 \%$ sodium chloride solution) and administered orally by drinking, as described elsewhere $(14,16)$. To adjust drug concentration to changes in body weight and fluid intake, the solutions were prepared freshly three times a week.

Body weight, fluid intake, and diuresis were measured twice a week over a 24 -h period as previously described $(14,16)$. To avoid contamination of urinary samples, the animals were housed in metabolic cages for $24 \mathrm{~h}$. Natriuria was determined by measuring sodium concentration 
with a selective electrochemical detector (AVL988-4, AVL LIST GMBH, Graz, Austria). Blood pressure measurements were performed three times/week using the tail cuff method (BP recorder, Ugo Basile, Comerio, Italy). When $50 \%$ mortality was reached in a treatment group, surviving animals were killed to study chronic lesions. The other animals that did not reach $50 \%$ mortality were killed at different time intervals $(14,16)$. In this paper, we focused on aortic wall remodeling.

The animals were killed under deep anesthesia with ketamine hydrochloride (ketamine, Ketalar, Parke-Davis, $100 \mathrm{mg} / \mathrm{kg}$ intraperitoneally). Animals used for morphology studies were transcardiacally perfused with $100 \mathrm{ml}$ of saline solution, followed by $100 \mathrm{ml}$ of ice cold Zamboni fixative, as previously described $(14,16)$. Aortic samples from nonperfused animals were used for biochemical analyses. All procedures were in agreement with The guide for the care and use of laboratory animals (National Institutes of Health publication no. 8523, revised 1985) and approved by local authorities.

\section{Tissue processing}

Thoracic aorta fixed by perfusion was removed and postfixed at $4^{\circ} \mathrm{C}$ for 24 additional hours in $2.5 \%$ glutaraldehyde in Tyrode solution, $\mathrm{pH} 7.2$, containing $0.1 \%$ toluidine blue to visualize glycosaminoglycans. The samples were washed in Tyrode solution, postfixed with $1 \%$ osmium tetroxide for $2 \mathrm{~h}$ at room temperature, dehydrated in a graded ethanol series, and embedded in spurr resin (Polysciences, Warrington, PA, U.S.A.).

\section{Light and electron microscopy}

Semithin true cross-sections (1-1.5 $\mu \mathrm{m}$ thick) of each fragment adjusted for vessel orientation were cut on a Reichert-Jung ultramicrotome, collected on slides, flattened, dried, and postpolymerized on a hot plate at $150^{\circ} \mathrm{C}$. Differential staining of the aortic wall components was obtained by processing sections with malachite green and basic fuchsin solutions, giving greenblue cells, violet-blue elastic fibers, and magenta collagen fibers and soluble matrix (18). The sections were observed under a Zeiss (Munich, Germany) Axiophot light microscope and images at $157.5 \times$ total magnification were collected for the morphometric analysis. Thin sections from the same cross-oriented samples were collected on 200-mesh nickel grids, stained with uranyl acetate and lead citrate or with tannic acid specific for elastic fibers, and examined under a JEOL 1200EXII electron microscope.

\section{Histomorphometry}

At least 12 images (comprehensive of the intima through the adventitia) were evaluated from three differ- ent aortic fragments of each animal using an automated image analysis system, consisting of a personal computer equipped with a frame grabber (Imascan Prism, Imagraph, Chelmsford, MA, U.S.A.), a scanner (Epson filmscan 200), and image analysis software (Image Pro Plus, Soft Imaging Software GmbH, Munster, Germany). Sampled areas from each image selected between the internal and external elastic lamina, corresponding to the tunica media, were digitized by scanning and filtered by software to separate the differently stained tissue components. Assuming homogeneity of staining for each sample, the means and finally the percentages of areas corresponding, respectively, to elastic fibers, matrix, and smooth muscle cells were evaluated. The aortic wall thickness was calculated as the distance between the internal and the external elastic lamina. At least five measurements per each aortic fragment were performed using the same image analysis system.

\section{Biochemical measurements}

Biochemical determinations of 4-OH-proline (a marker of collagen content) and desmosines (desmosine and isodesmosine, indexes of protein cross-links generally referred to elastin) were performed directly on whole tissue hydrolysates. Frozen aortic samples were freezedried for $48 \mathrm{~h}$ in a Lyovac GT2 lyophilizer (LeyBold Technologies, Milan, Italy) and chemically hydrolyzed with $6 \mathrm{~N} \mathrm{HCl}$ for $72 \mathrm{~h}$ at $110^{\circ} \mathrm{C}$ in sealed glass tubes.

To determine 4-OH-proline concentration, aorta hydrolysates were evaporated under vacuum at $45^{\circ} \mathrm{C}$, the residues dissolved in $0.003 \mathrm{~N} \mathrm{HCl}$ and applied to a column with analytical grade cation-exchange resins (52-100 mesh H+; BDH, Milan, Italy). The column was then washed with water and eluted with $2 \mathrm{~N} \mathrm{NH}_{3}$. After evaporation under a vacuum at $45^{\circ} \mathrm{C}$, the eluates were resuspended in water, buffered with $0.1 \mathrm{M}$ borate (pH 9.1), and oxidized with a chloramine $\mathrm{T}$ solution (19). Oxidation was stopped with Ehrlich reactive. After incubation in a shaking thermostatic bath at $65^{\circ} \mathrm{C}$ and subsequent cooling, samples were extracted in $6 \mathrm{M}$ of $\mathrm{NaOH}$ and toluene. The water-insoluble phase was added to $0.03 \mathrm{~N} \mathrm{HCl}$ and centrifuged (3,000 rpm). The concentration of 4-OH-proline was measured at 550 $\mathrm{nm}$ wavelength in a Beckmann (Milan, Italy) DU 650 spectrophotometer.

Desmosine and isodesmosine cross-links in aortic hydrolysates were determined by high-performance liquid chromatography (20). Dried hydrolysates of aorta were resuspended in $6 \mathrm{~N} \mathrm{HCl}$, acetic acid, and n-butanol 1:1:4 (solution A) and applied to a cellulose column that was then washed with $40 \mathrm{ml}$ of acetic acid, water, and n- 
butane 1.1:1:4 (solution B) and eluted with water. The eluates were finally evaporated under vacuum and derivatizated solutions were obtained by sequentially adding $410 \mu \mathrm{l}$ of $0.4-M$ borate buffer, $\mathrm{pH} 9$, dissolved in methanol (8:2); $30 \mu l$ of internal standard (acetyl-1lysine; 4-dimethyl-amino-azo-benzene, 4 sulfonylchloride); $20 \mu \mathrm{l}$ of $0.1 \mathrm{M} \mathrm{KCN}$ in water; and $40 \mu \mathrm{l}$ of 30-mM 2,3-naphthalen-dicarboxy-aldehyde in methanol. The derivatizated solutions were shaken and injected in the high-performance liquid chromatography apparatus (Beckmann System Gold, Programmable Solvent Module 126 and Diode Array Detector Module 168) equipped with a precolumn LiChrospher 60 RP-Select $5 \mathrm{~mm}$ (LiChroCart) and a Supelcosil LC-18-DB column (15-cm length, 4.6-mm thickness, 3-mm particle size, Supelco, Milan, Italy). The mobile phase was composed of two different solvents: solvent A, consisting of $0.005 \mathrm{M}$ of tribasic sodium citrate and $0.05 \mathrm{M}$ of sodium perchlorate, and solvent $\mathrm{B}$, composed of $0.05 \mathrm{M}$ of sodium perchlorate in methanol. The flow of solvent A was set to 0.55 $\mathrm{ml} / \mathrm{min}$ and mixed in different percentages with solvent B. The samples were analyzed with a deuterium lamp (D2 Beckmann) at $420 \mathrm{~nm}$ wavelength.

\section{Statistical methods}

Results from arterial blood pressure measurements obtained in the 3 weeks preceding the killing were averaged and analyzed by means of one-way analysis of variance (ANOVA) followed by Dunnett test. Sodium intake and excretion were analyzed by ANOVA for repeated measures and post hoc Games-Howell test for multiple comparisons. Biochemical and histomorphometric data were analyzed by one-way ANOVA and Games-Howell test. Results are presented as mean $\pm \mathrm{SD}$, assuming $\mathrm{p}<0.05$ as the level of significant difference. Statistical analysis was performed using the Statistical Package for the Social Sciences, version 8.0 (Chicago, IL, U.S.A., 1998).

\section{RESULTS}

\section{Treatment effects on hypertension}

As reported in the literature, SHRsp maintained on a high-sodium diet presented a higher mortality (half-life $=14$ weeks of age, 6 weeks of treatment) (17). Data on survival, body weight gain, fluid intake, diuresis, blood pressure (measured by the tail-cuff method), and organ lesions in delapril- and indapamide-treated SHRsp have already been reported $(14,16)$. Therefore, in the present paper we reevaluated the changes in blood pressure levels by performing an intergroup/experiment comparison at the time the animals were killed (Table 1). According to this analysis, delapril and indapamide combination at the highest doses effectively controlled hypertension, resulting in significantly $(\mathrm{p}<0.01$ ) lower blood pressure values (approximately $60 \mathrm{~mm} \mathrm{Hg}$ less) than values in controls. Instead, the other treatments proved to be ineffective.

\section{Effects of delapril and indapamide combined treatments on sodium balance}

In experiment 2, we examined the effects of delapril and indapamide combination on sodium intake and excretion, to monitor the degree of salt loading in relation to hypertension and lesion appearance. Data on differences in sodium excretion before and after the beginning of salt loading are known (16). As illustrated in Fig. 1, sodium intake steeply increased in rats treated with delapril $1.5 \mathrm{mg} / \mathrm{kg} / \mathrm{d}+$ indapamide $0.125 \mathrm{mg} / \mathrm{kg} / \mathrm{d}$ from the 9th week of treatment onward, accompanied by similar changes in natriuresis. In these animals sodium intake, but not sodium excretion, declined in the last 4 weeks, suggesting a progressive reduction in sodium balance. In animals treated with delapril $3 \mathrm{mg} / \mathrm{kg} / \mathrm{d}+$ indapamide $0.25 \mathrm{mg} / \mathrm{kg} / \mathrm{d}$, sodium intake was generally significantly lower than in rats treated with delapril $6 \mathrm{mg} / \mathrm{kg} / \mathrm{d}+$ indapamide $0.5 \mathrm{mg} / \mathrm{kg} / \mathrm{d}$ (Fig. 1A), and slowly declined after the 3 rd week of treatment (when it peaked) up to the

TABLE 1.

Effect of delapril, indapamide and their combinations on arterial blood pressure levels in SHRsp

\begin{tabular}{lccccccc}
\hline Treatments & Sal & De12 & In1 & De12ln1 & De6ln0.5 & De3ln0.25 & De1.5ln0.125 \\
\hline Age (weeks) & 14 & 33 & 33 & 30 & 51 & 51 & 25 \\
Blood Pressure (mm Hg) & $273 \pm 22$ & $270 \pm 22$ & $265 \pm 13$ & $228 \pm 8^{* * *}$ & $261 \pm 20$ & $276 \pm 21$ & $289 \pm 7$ \\
\hline
\end{tabular}

Blood pressure values of the last three weeks before killing were averaged and compared.

De12, delapril $12 \mathrm{mg} / \mathrm{kg}$; In1, indapamide $1 \mathrm{mg} / \mathrm{kg}$; De12In1, delapril12 mg/kg + indapamide $1 \mathrm{mg} / \mathrm{kg}$; De1.5In0.125, delapril $1.5 \mathrm{mg} / \mathrm{kg}+$ indapamide $0.125 \mathrm{mg} / \mathrm{kg}$; De3In0.25, delapril $3 \mathrm{mg} / \mathrm{kg}+$ indapamide 0.25 $\mathrm{mg} / \mathrm{kg}$; De6In0.5, delapril $6 \mathrm{mg} / \mathrm{kg}+$ indapamide $0.5 \mathrm{mg} / \mathrm{kg}$; Sal, saline-treated SHRsp.

${ }^{*} \mathrm{p}<0.05$ and $* * \mathrm{p}<0.01$ vs saline-treated SHRsp (control group), Dunnett test. 

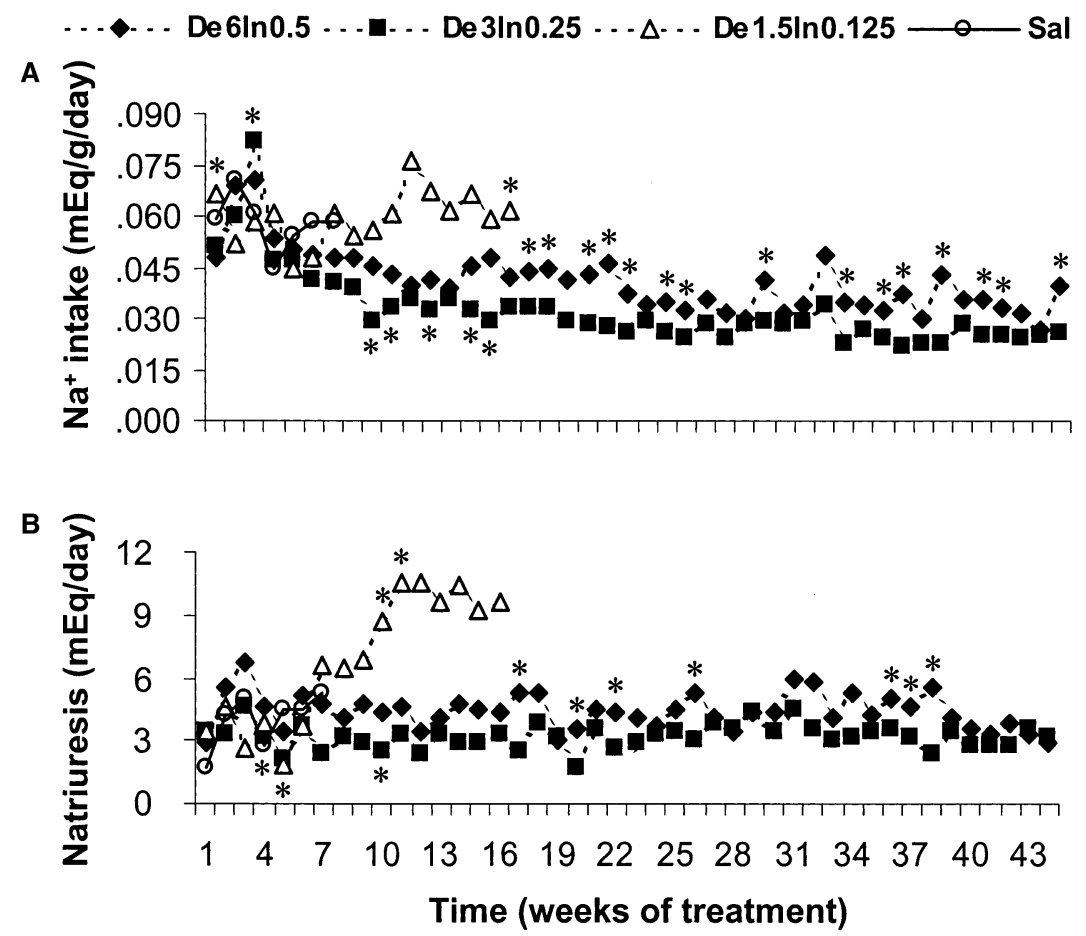

FIG. 1. Sodium intake and renal excretion in stroke-prone spontaneously hypertensive rats (SHRsp) treated with different delapril and indapamide combination doses. A. Sodium intake $(\mathrm{mEq} / \mathrm{d})$ was deduced from fluid intake $(1 \%$ sodium chloride solution) and normalized by body weight $(\mathrm{g})$. B. Sodium excretion measured after a daily $(24-\mathrm{h})$ urine collection. De1.5 $\ln 0.125=$ delapril $1.5+$ indapamide 0.125 $\mathrm{mg} / \mathrm{kg}$; De3ln0.25 = delapril $3 \mathrm{mg} / \mathrm{kg}$ + indapamide $0.25 \mathrm{mg} / \mathrm{kg}$; De6ln0.5 = delapril $6 \mathrm{mg} / \mathrm{kg}$ + indapamide $0.5 \mathrm{mg} / \mathrm{kg}$; Sal = saline. ${ }^{*} \mathrm{p}<$ 0.05 versus 1 treatment group, Games-Howell test for multiple comparisons.

end of the experiment. However, sodium excretion was almost stable in this group (Fig. 1B), suggesting a progressive decrease in salt-loading efficacy in SHRsp treated with delapril $3 \mathrm{mg} / \mathrm{kg} / \mathrm{d}+$ indapamide 0.25 $\mathrm{mg} / \mathrm{kg} / \mathrm{d}$. After the $3 \mathrm{rd}$ week of treatment, sodium intake declined in rats treated with delapril $6 \mathrm{mg} / \mathrm{kg} / \mathrm{d}+$ indapamide $0.5 \mathrm{mg} / \mathrm{kg} / \mathrm{d}$ as in animals treated with delapril 3 $\mathrm{mg} / \mathrm{kg} / \mathrm{d}+$ indapamide $0.25 \mathrm{mg} / \mathrm{kg} / \mathrm{d}$, but less consistently (Fig. 1A). Natriuresis was significantly higher in animals treated with delapril $6 \mathrm{mg} / \mathrm{kg} / \mathrm{d}+$ indapamide 0.5 $\mathrm{mg} / \mathrm{kg} / \mathrm{d}$ than in animals treated with delapril $3 \mathrm{mg} / \mathrm{kg} / \mathrm{d}$ + indapamide $0.25 \mathrm{mg} / \mathrm{kg} / \mathrm{d}$ in 8 of 44 weeks of the study (Fig. 1B), but not enough to compensate for differences found in sodium intake among the two groups.

\section{Biochemical evaluation of extracellular matrix markers}

Drug treatments differently affected the biochemical composition of the aortic wall (Table 2). In animals treated with delapril $12 \mathrm{mg} / \mathrm{kg} / \mathrm{d}$, highly significant increases in 4-OH-proline ( $\mathrm{p}<0.01)$ and desmosine content $(\mathrm{p}<0.05)$ were observed with respect to the drugfree salt-loaded group. Significantly increased levels of
4-OH-proline ( $\mathrm{p}<0.05$ versus the drug-free salt-loaded group) were found also in animals treated with indapamide $1 \mathrm{mg} / \mathrm{kg} / \mathrm{d}$. By contrast, 4-OH-proline amounts in animals treated with delapril $12 \mathrm{mg} / \mathrm{kg} / \mathrm{d}+$ indapamide 1 $\mathrm{mg} / \mathrm{kg} / \mathrm{d}$ were very similar to those found in the drug-free salt-loaded group and were significantly lower than those in the other age-matched treatment groups (Table 2). Desmosine cross-links instead increased significantly with combined drugs ( $\mathrm{p}<0.01$ versus the drug-free saltloaded group) as in the other drug treatment groups.

\section{Histomorphometric findings}

In experiment 1 , significant effects of the delapril and indapamide combination on aortic wall remodeling were observed. As shown in Fig. 2A, vessel wall thickening was significantly ( $\mathrm{p}<0.01$ ) lower (about $20 \%$ less) in rats treated with delapril $12 \mathrm{mg} / \mathrm{kg} / \mathrm{d}+$ indapamide 1 $\mathrm{mg} / \mathrm{kg} / \mathrm{d}$ than in animals treated with delapril $12 \mathrm{mg} / \mathrm{kg} / \mathrm{d}$ or indapamide $1 \mathrm{mg} / \mathrm{kg} / \mathrm{d}$. At histomorphometry, the delapril $12 \mathrm{mg} / \mathrm{kg} / \mathrm{d}$ and indapamide $1 \mathrm{mg} / \mathrm{kg} / \mathrm{d}$ treatment groups had a significantly $(\mathrm{p}<0.01$ versus rats treated with delapril $12 \mathrm{mg} / \mathrm{kg} / \mathrm{d}+$ indapamide $1 \mathrm{mg} / \mathrm{kg} / \mathrm{d}$ ) increased matrix density (about $+40 \%$ ). Conversely, elastic 
TABLE 2.

Changes in the biochemical composition of the aortic wall evaluated by measuring 4-OH-proline, desmosine and isodesmosine (indicated as desmosines) levels

\begin{tabular}{lcccc}
\hline Treatments & Sal & De12 & In1 & De12In1 \\
\hline $\mathrm{n}$ & 6 & 6 & 4 & 4 \\
4-OH-proline & $11.09 \pm 4.30$ & $24.51 \pm 4.18^{* * \# \#}$ & $21.74 \pm 4.10^{* \#}$ & $7.99 \pm 0.97$ \\
Desmosines & $0.38 \pm 0.09$ & $0.91 \pm 0.21^{*}$ & $0.70 \pm 0.20$ & $0.59 \pm 0.02^{* *}$ \\
\hline
\end{tabular}

Control rats (Sal) were 14 weeks-old, drug-treated rats were instead 33 (De12, In1) and 30 (De12In1) weeks-old. All values are expressed as $\mu \mathrm{g} / \mathrm{mg}$ of aortic dry defatted weight.

De12, delapril $12 \mathrm{mg} / \mathrm{kg}$; In1, indapamide $1 \mathrm{mg} / \mathrm{kg}$; De12In1, delapril12 mg/kg + indapamide $1 \mathrm{mg} / \mathrm{kg}$; Sal, saline.

${ }^{*} \mathrm{p}<0.05, * * \mathrm{p}<0.01$ vs. Sal SHRsp; \#p $<0.05, \#$ p $<0.01$ vs. De12In1 SHRsp,

Games-Howell test for multiple comparisons.

fiber density decreased (about $-25 \%$ ) with respect to rats treated with delapril $12 \mathrm{~m} / \mathrm{gk} / \mathrm{g}+$ indapamide $1 \mathrm{mg} / \mathrm{kg} / \mathrm{d}$ (Fig. 3A).

In experiment 2, no differences were observed when considering aortic wall thickness (Fig. 2B), in spite of the age differences between animals treated with delapril 1.5 $\mathrm{mg} / \mathrm{kg} / \mathrm{d}+$ indapamide $0.125 \mathrm{mg} / \mathrm{kg} / \mathrm{d}$ and the other groups (Table 1). By contrast, well-defined dose-related changes in matrix density were appreciated on histomorphometry (Fig. 3B). In fact, matrix levels were significantly ( $p<0.05$ versus all other groups) higher in animals treated with delapril $1.5 \mathrm{mg} / \mathrm{kg} / \mathrm{d}+$ indapamide

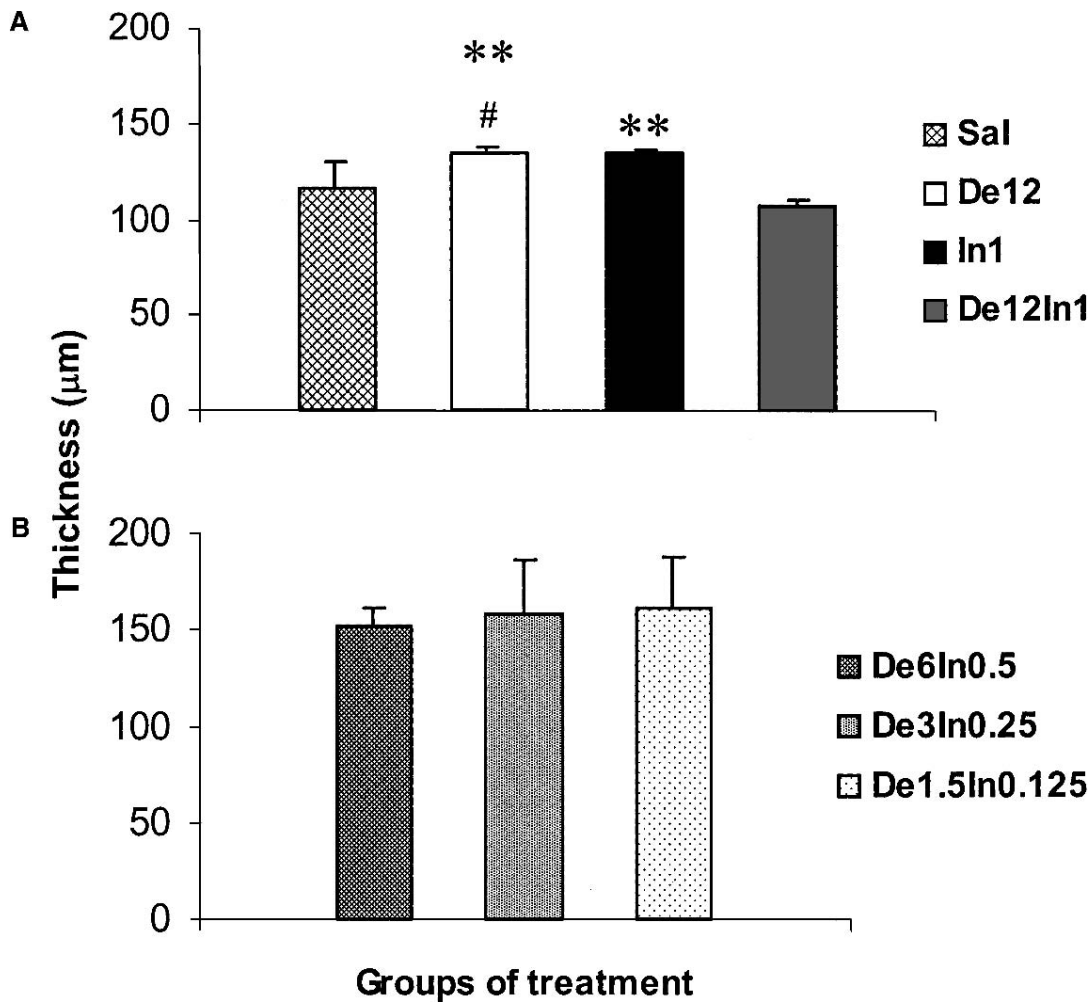

FIG. 2. Changes in aortic wall thickness in saline-treated (A) or drug-treated (B) stroke-prone spontaneously hypertensive rats (SHRsp). Means represent the distance between internal and external elastic lamina. Control rats (Sal) were 14 weeks old. Drug-treated rats were instead 33 (De12, In1), 30 (De12ln1), 51 (De6ln0.5, De3ln0.25), and 25 (De1.5ln0.125) weeks old. Sal = saline; De12= delapril $12 \mathrm{mg} / \mathrm{kg}$; De1.5In0.125 = delapril $1.5 \mathrm{mg} / \mathrm{kg}$ + indapamide $0.125 \mathrm{mg} / \mathrm{kg}$; De3ln0.25 = delapril $3 \mathrm{mg} / \mathrm{kg}$ + indapamide $0.25 \mathrm{mg} / \mathrm{kg}$; De6 $\mathrm{ln} 0.5=$ delapril $6 \mathrm{mg} / \mathrm{kg}+$ indapamide $0.5 \mathrm{mg} / \mathrm{kg}$; De12ln1 = delapril $12 \mathrm{mg} / \mathrm{kg}+$ indapamide $1 \mathrm{mg} / \mathrm{kg} ; \mathrm{ln} 1$ = indapamide $1 \mathrm{mg} / \mathrm{kg}$. ${ }^{* *} \mathrm{p}<0.01 \mathrm{versus}$ De12ln1-treated SHRsp; \#p < 0.05 versus Sal-treated SHRsp, Games-Howell test for multiple comparisons. 


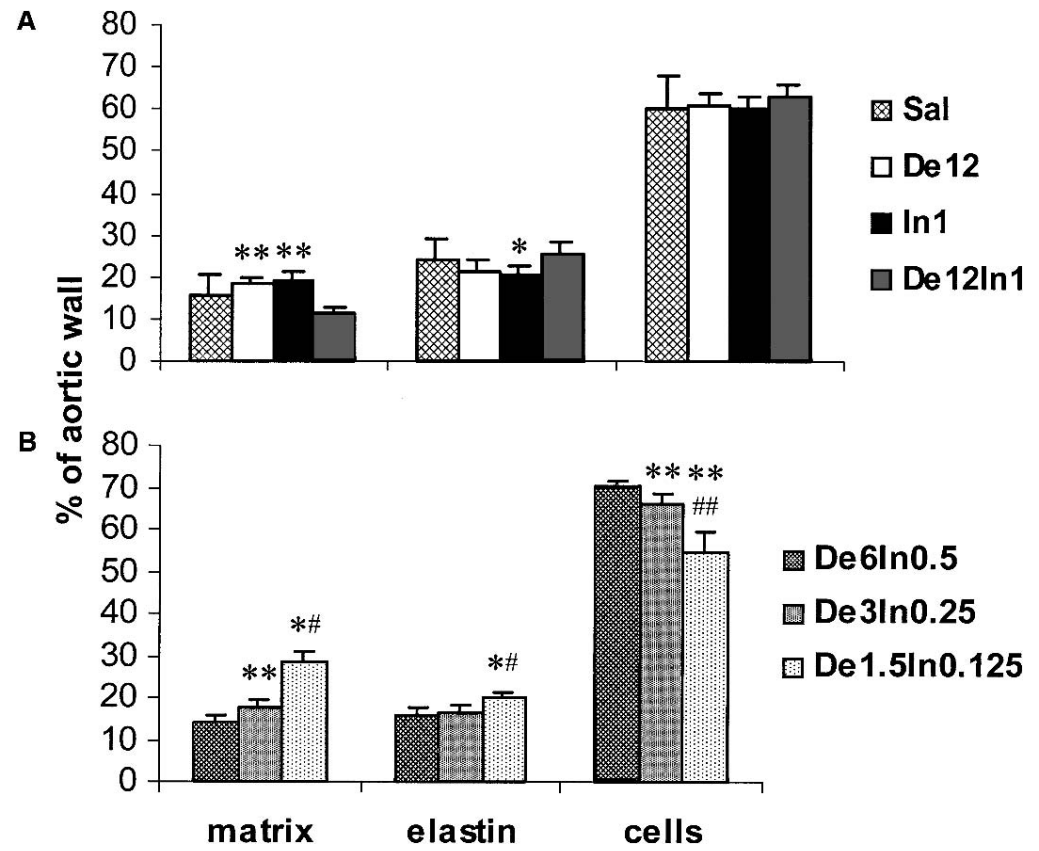

FIG. 3. Histomorphometry of changes in the aortic wall composition of stroke-prone spontaneously hypertensive rats (SHRsp) following saline $(\mathbf{A})$ or drug $(\mathbf{B})$ treatments. Sal = saline; De12 = delapril $12 \mathrm{mg} / \mathrm{kg} ;$ De1.5In0.125 = delapril $1.5+$ indapamide $0.125 \mathrm{mg} / \mathrm{kg}$; De3ln0.25 = delapril $3 \mathrm{mg} / \mathrm{kg}$ + indapamide $0.25 \mathrm{mg} / \mathrm{kg}$; De6ln0.5 = delapril $6 \mathrm{mg} / \mathrm{kg}$ + indapamide $0.5 \mathrm{mg} / \mathrm{kg}$; De12ln1 = delapril $12 \mathrm{mg} / \mathrm{kg}$ + indapamide $1 \mathrm{mg} / \mathrm{kg}$; In1 = indapamide $1 \mathrm{mg} / \mathrm{kg}$. A. ${ }^{*} \mathrm{p}<0.05$, ${ }^{\star *} \mathrm{p}<0.01$ versus De12ln1-treated SHRsp. B. ${ }^{*} \mathrm{p}<0.05$, ${ }^{* *} \mathrm{p}<0.01 \mathrm{versus}$ De6In0.5-treated SHRsp; \#p $<0.05$, \#\#p $<0.01$ versus De3In0.25-treated SHRsp, Games-Howell test for multiple comparisons.

$0.125 \mathrm{mg} / \mathrm{kg} / \mathrm{d}$ and decreased progressively with increasing combination doses. Elastic fiber density was also significantly $(\mathrm{p}<0.05)$ higher in animals treated with delapril $1.5 \mathrm{mg} / \mathrm{kg} / \mathrm{d}+$ indapamide $0.125 \mathrm{mg} / \mathrm{kg} / \mathrm{d}$ than in the other treatment groups, probably because this group was composed of younger animals (Table 1). Cell density instead was significantly $(\mathrm{p}<0.01)$ lower in animals treated with delapril $1.5 \mathrm{mg} / \mathrm{kg} / \mathrm{d}+$ indapamide 0.125 $\mathrm{mg} / \mathrm{kg} / \mathrm{d}$ as compared with animals treated with delapril $3 \mathrm{mg} / \mathrm{kg} / \mathrm{d}+$ indapamide $0.25 \mathrm{mg} / \mathrm{kg} / \mathrm{d}$ and those treated with delapril $6 \mathrm{mg} / \mathrm{kg} / \mathrm{d}+$ indapamide $0.5 \mathrm{mg} / \mathrm{kg} / \mathrm{d}$. A significant $(\mathrm{p}<0.01)$ difference in matrix and cell density was also found between the delapril $3 \mathrm{mg} / \mathrm{kg} / \mathrm{d}+$ indapamide $0.25 \mathrm{mg} / \mathrm{kg} / \mathrm{d}$ and delapril $6 \mathrm{mg} / \mathrm{kg} / \mathrm{d}+$ indapamide $0.125 \mathrm{mg} / \mathrm{kg} / \mathrm{d}$ treatment groups.

\section{Ultrastructural analysis of aortic remodeling}

Drug treatment effects on SHRsp aorta ultrastructural features were analyzed in animals treated with scaled doses of the combination. In Fig. 4, a combination of drug- and age-dependent effects on aortic wall remodeling is illustrated. In rats treated with delapril $6 \mathrm{mg} / \mathrm{kg} / \mathrm{d}$ + indapamide $0.5 \mathrm{mg} / \mathrm{kg} / \mathrm{d}$ (Fig. 4A) and rats treated with delapril $3 \mathrm{mg} / \mathrm{kg} / \mathrm{d}+$ indapamide $0.25 \mathrm{mg} / \mathrm{kg} / \mathrm{d}$ (Fig. 4B) that survived until age 51 weeks, a notable thinning of elastic laminae was observed as compared with 25 -weekold animals treated with delapril $1.5 \mathrm{mg} / \mathrm{kg} / \mathrm{d}+$ indapamide $0.125 \mathrm{mg} / \mathrm{kg} / \mathrm{d}$ (Fig. 4C). However, the elastic laminae presented a better morphology in the animals treated with highest doses of drug combination, because in those receiving delapril $1.5 \mathrm{mg} / \mathrm{kg} / \mathrm{d}+$ indapamide $0.125 \mathrm{mg} / \mathrm{kg} / \mathrm{d}$ they were highly irregularly shaped. The other components of the extracellular matrix seemed to be increased to a greater extent in younger (delapril 1.5 $\mathrm{mg} / \mathrm{kg} / \mathrm{d}+$ indapamide $0.125 \mathrm{mg} / \mathrm{kg} / \mathrm{d}$ group) than older (delapril $3 \mathrm{mg} / \mathrm{kg} / \mathrm{d}+$ indapamide $0.25 \mathrm{mg} / \mathrm{kg} / \mathrm{d}$ and delapril $6 \mathrm{mg} / \mathrm{kg} / \mathrm{d}+$ indapamide $0.5 \mathrm{mg} / \mathrm{kg} / \mathrm{d}$ combination-treated rats, suggesting a failure of the lowest doses to protect the aortic wall. In addition, signs of cell atrophy were visible in rats treated with delapril $1.5 \mathrm{mg} / \mathrm{kg} / \mathrm{d}$ + indapamide $0.125 \mathrm{mg} / \mathrm{kg} / \mathrm{d}$. By contrast, smooth muscle cells were apparently normal in animals treated with the highest drug combination doses. Thus, differences in matrix and relative cell densities found at histomorphometry after combined drug treatment (Fig. 3B) could be related to a higher matrix deposition and cell atrophy in younger (delapril $1.5 \mathrm{mg} / \mathrm{kg} / \mathrm{d}+$ indapamide $0.125 \mathrm{mg} / \mathrm{kg} / \mathrm{d}$ ) as compared with older (delapril 3 $\mathrm{mg} / \mathrm{kg} / \mathrm{d}+$ indapamide $0.5 \mathrm{mg} / \mathrm{kg} / \mathrm{d}$ and delapril 6 $\mathrm{mg} / \mathrm{kg} / \mathrm{d}+$ indapamide $0.5 \mathrm{mg} / \mathrm{kg} / \mathrm{d}$ ) SHRsp. 


\section{DISCUSSION}
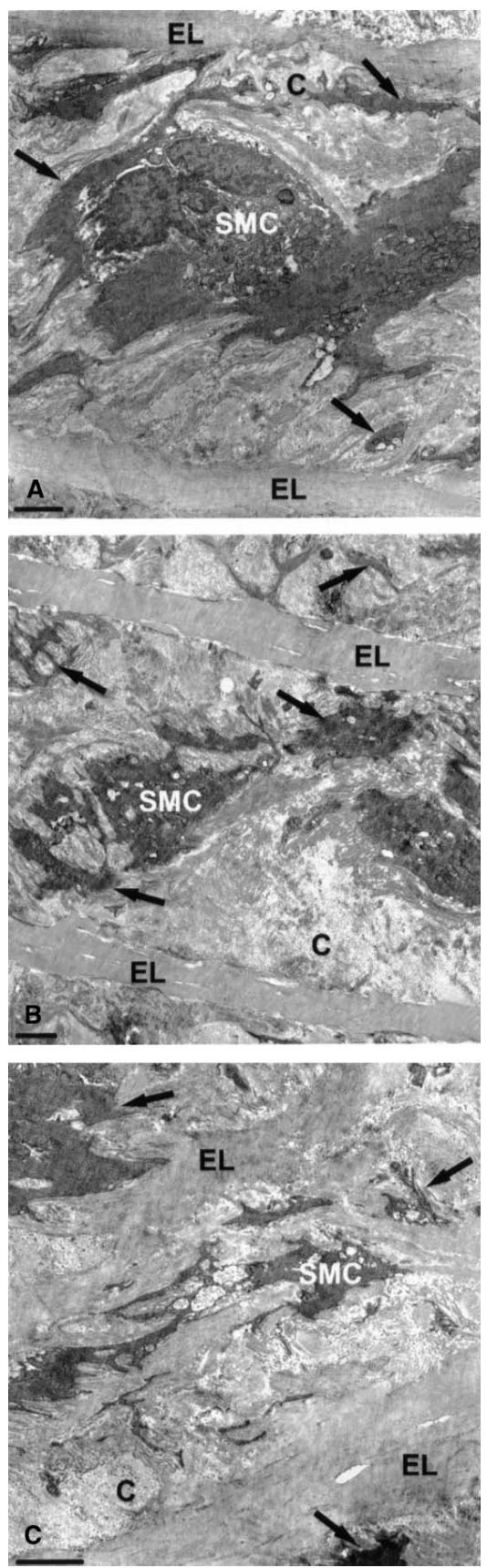

FIG. 4. Electron microscopy of the aortic wall from SHRsp treated with different delapril and indapamide combination doses. A portion of tunica media between two elastic laminae is shown for delapril $6 \mathrm{mg} / \mathrm{kg}$ + indapamide $0.5 \mathrm{mg} / \mathrm{kg}$ (A), delapril $3 \mathrm{mg} / \mathrm{kg}$ + indapamide $0.25 \mathrm{mg} / \mathrm{kg}$ (B), and delapril 1.5 + indapamide $0.125 \mathrm{mg} / \mathrm{kg}$ (C) treatments. The arrows point to smooth muscle cells. C, collagen; EL, elastic lamina; SMC, smooth muscle cell. Scale bars $=2 \mu \mathrm{m}$.
We analyzed the effects of chronic anti-hypertensive drug treatment on the thoracic aortic wall of salt-loaded SHRsp. To our knowledge, this is the only study following SHRsp aortic alterations in the long term (approximately 1 year in combined drug treatments); thus it cannot be compared with similar studies that showed beneficial effects of ACE inhibitors and thiazides in the short term $(11,21-24)$. Due to salt-loading procedure, our study was limited by the age differences occurring between the groups with high (drug-free salt-loaded rats and rats treated with delapril $1.5 \mathrm{mg} / \mathrm{kg} / \mathrm{d}+$ indapamide $0.125 \mathrm{mg} / \mathrm{kg} / \mathrm{d}$ ), medium (delapril $12 \mathrm{mg} / \mathrm{kg} / \mathrm{d}$-, indapamide $1 \mathrm{mg} / \mathrm{kg} / \mathrm{d}$-, and delapril $12 \mathrm{mg} / \mathrm{kg} / \mathrm{d}+$ indapamide $1 \mathrm{mg} / \mathrm{kg} / \mathrm{d}$-treated rats), and low (delapril $3 \mathrm{mg} / \mathrm{kg} / \mathrm{d}+$ indapamide $0.25 \mathrm{mg} / \mathrm{kg} / \mathrm{d}$ - and delapril $6 \mathrm{mg} / \mathrm{kg} / \mathrm{d}+$ indapamide $0.5 \mathrm{mg} / \mathrm{kg} / \mathrm{d}$-treated rats) mortality rate. Accordingly, differences in elastin and cell density between the younger (salt loaded and delapril $1.5 \mathrm{mg} / \mathrm{kg} / \mathrm{d}+$ indapamide $0.125 \mathrm{mg} / \mathrm{kg} / \mathrm{d}$ ) and the other older groups of treatment might be explained by the aging processes of the aortic wall (25). Moreover, the lowest values of cell density were found in rats treated with delapril 1.5 $\mathrm{mg} / \mathrm{kg} / \mathrm{d}+$ indapamide $0.125 \mathrm{mg} / \mathrm{kg} / \mathrm{d}$, supporting the hypothesis of a larger damage to smooth muscle cells caused by persistence of very high blood pressure levels in this group as compared with controls (16). This hypothesis was further strengthened by ultrastructural analysis that demonstrated atrophic smooth muscle cells in this treatment group.

Conversely, we were able to demonstrate an ageindependent effect of drug treatments. Indeed, aortic thickness in 30-week-old combination-treated rats (delapril $12 \mathrm{mg} / \mathrm{kg} / \mathrm{d}+$ indapamide $1 \mathrm{mg} / \mathrm{kg} / \mathrm{d}$ ) was found to be comparable to that of 14-week-old controls. This finding suggests that combination treatment was able to antagonize aortic wall thickening that occurs in aged SHRsp (Baccarani Contri et al., in preparation). By contrast, delapril or indapamide administered separately both failed to preserve aortic size. These findings were corroborated by histomorphometric data showing significantly lower matrix levels in combination-treated rats, in which a clear dose-response effect with scaled doses of the combination was also found. These semiquantitative results, obtained by calculating the relative density of each component as percent of tunica media area, were in line with the biochemical findings that demonstrated a significantly lower 4-OH-proline concentration in combination-treated rats. Desmosine levels were instead comparable between the various drug treatment groups. This is in contrast with histomorphometric findings that 
show a significantly higher elastin density in combination as compared with indapamide-treated SHRsp. As desmosines are markers of mature cross-linked elastin (20), this result suggests an enhanced production or decreased processing of immature elastin in combinationtreated animals.

In humans as in hypertensive animals, stiffening of large vessels can increase systolic blood pressure and pulse pressure $(26,27)$, leading to heart hypertrophy and favoring cardiovascular mortality $(1,9,26,27)$. Notably, we found that delapril and indapamide combined treatments, although ineffective in lowering arterial blood pressure values in SHRsp, were able to antagonize aortic wall thickening due to increased matrix synthesis, as evaluated by histomorphometry, biochemistry, and electron microscopy. Blood pressure levels were substantially stabilized at the highest combination doses, but no effects on blood pressure were observed with decreasing doses that maintained comparable protective effects on the aortic wall. These findings suggest that the drugs we used possess anti-fibrotic properties that are not related to their anti-hypertensive effects. Although ACE inhibitors are known to prevent fibrosis in the SHR aortic wall (3), indapamide administered at a dose of $3 \mathrm{mg} / \mathrm{kg}$ was found to be ineffective in salt-loaded SHRsp (21). Our results demonstrate that indapamide administered at 1 $\mathrm{mg} / \mathrm{kg}$ has effects equivalent to those found with delapril administered at $12 \mathrm{mg} / \mathrm{kg}$ on matrix deposition in the aortic wall and that a substantial improvement could be achieved by combining them. Similar findings were also obtained in the aortic wall of SHRs maintained on a normal diet by combining perindopril and indapamide treatment, but in this case a significant difference in blood pressure levels between control and drug-treated rats was found at any dose used (22). Thus, to our knowledge this is the first time that these beneficial effects of the ACE inhibitor and thiazide combination have been shown to be independent of anti-hypertensive properties.

Vessel wall fibrosis has been shown to be limited by ACE inhibitors via a direct antagonism of angiotensin II synthesis $(3,23)$. In fact, locally produced angiotensin II controls the synthesis of collagen in the arterial wall directly or by inducing autocrine/paracrine mediators, such as transforming growth factor (TGF)- $\beta 1$ (4). Dietary sodium chloride is capable of inducing TGF- $\beta 1$ and stimulating kinin synthesis, affecting the structure of arterial blood vessels (11). These effects could explain why ACE inhibitors were found to lose their protective properties in the presence of salt loading $(12,13)$. We previously observed that delapril $12 \mathrm{mg} / \mathrm{kg}$ combined with indapamide $1 \mathrm{mg} / \mathrm{kg}$, i.e., the highest dose tested, is capable of stimulating diuresis, suggesting the possibility that the negative effects of salt loading on ACE inhibition and vessel wall could be prevented by increased sodium excretion (14). This effect could explain the limited fibrosis found in the aortic wall of animals treated with the highest doses of the combination. To challenge this hypothesis, we analyzed the effects of scaled doses of the combined drugs on sodium excretion and aortic wall fibrosis. We found that a half-dose of the highest dose combination maintained the protective effects on the aortic wall intact but lacked diuretic properties. A further half-dose of delapril and indapamide combination showed attenuated but still evident vascular protective effects. Conversely, we did not observe consistent differences in sodium balance or arterial blood pressure between the groups receiving these scaled drug doses. Only in rats treated with very low combination doses (1 of 8 of the highest doses) were no protective effects found on aortic wall changes. However, in this last case the sodium balance was greatly affected, possibly in relation to renal damage (16).

We cannot clearly explain the synergistic effects of the drug combination. Indapamide has been shown to be a potent anti-oxidant (28), to antagonize calcium influx in smooth muscle cells (29), and to modulate nitric oxide synthesis in the SHR aorta when combined with ACE inhibitors (22). These data suggest that indapamide can directly affect vessel wall properties. Recently, Pickkers et al. $(30,31)$ showed that thiazide diuretics can be accumulated by vascular smooth muscle cells reaching intracellular concentrations able to inhibit carbonic anhydrase, thus shifting intracellular $\mathrm{pH}$ to alkaline values. In turn, intracellular alkalinization can activate largeconductance calcium-activated potassium channels, producing vasorelaxant effects. Indeed, this effect could be synergistic with that of ACE inhibitors that, by lowering angiotensin II synthesis, decrease the activation of angiotensin II type 1 receptors and smooth muscle cell contraction (32). Interestingly, thiazide effects on carbonic anhydrase could take place at clinically relevant concentrations, explaining why their anti-hypertensive properties are independent of diuresis stimulation. Thus, it might prove worthy to investigate whether such direct modulation of smooth muscle cell activity is involved in the anti-hypertrophic/anti-fibrotic effects of indapamide demonstrated for the heart $(33,34)$ and large arteries $(35)$ and the possible interactions with ACE inhibitor effects.

In conclusion, we provide evidence that delapril and indapamide synergize to protect the aortic wall in extremely adverse conditions, such as those seen in the SHRsp genetic model of hypertension (in which blood vessels constitutively tend to develop pathologic changes) further strained by a sodium chloride-enriched 
diet. These findings encourage the reevaluation of diuretic and ACE inhibitor combinations as possible firstline treatment, aimed at preserving large vessels from the pathologic changes occurring in long-term hypertension. Interestingly, when patients manifest a poor compliance to aggressive anti-hypertensive treatments (36), the use of ACE inhibitor and thiazide diuretic combinations at lower doses can nonetheless be advantageous, because their cardiovascular protective properties appear to be largely independent of blood pressure-lowering and diuretic effects. Moreover, the growing evidence on direct vascular effects of ACE inhibitors and diuretics suggests that their clinical use should also be investigated in vascular diseases unrelated to hypertension.

Acknowledgments: The authors thank Dr. R. Razzetti for useful comments, Dr. A. Tombesi for the excellent technical assistance, and Ms. Rita Motalli for editorial assistance.

\section{REFERENCES}

1. Safar ME, London GM, Asmar R, et al. Recent advances on large arteries in hypertension. Hypertension 1998;32: 156-61.

2. Guyton JR, Dao DT, Lindsay KL, et al. Ultrastructure of hypertensive rat aorta: increased basement membrane-like material. Hypertension 1990;15:56-67.

3. Albaladejo P, Bouaziz H, Duriez M, et al. Angiotensin converting enzyme inhibition prevents the increase in aortic collagen in rats. Hypertension 1994;23:74-82.

4. Rosendorff $\mathrm{C}$. The renin-angiotensin system and vascular hypertrophy. J Am Coll Cardiol 1996;28:803-12.

5. Wolinsky H. Effects of hypertension and its reversal on the thoracic aorta of male and female rats: morphological and chemical studies. Circ Res 1971;28:622-37.

6. Schachter M. Drug-induced modification of vascular structure: effects of antihypertensive drugs. Am J Hypertens 1991;122:316-23.

7. Coca A. Actual blood pressure control: are we doing things right? J Hypertens 1998;16:S45-51.

8. Asmar R, Benetos A, London G, et al. Aortic distensibility in normotensive, untreated and treated hypertensive patients. Blood Press 1995;4:48-54.

9. Deedwania PC. The progression from hypertension to heart failure. Am J Hypertens 1997;10:280S-8S.

10. Siani A, Guglielmucci F, Farinaro E, et al. Increasing evidence for the role of salt and salt-sensitivity in hypertension. Nutr Metab Cardiovasc Dis 2000;10:93-100.

11. Safar ME, Thuilliez Ch, Richard V, et al. Pressureindependent contribution of sodium to large artery structure and function in hypertension. Cardiovasc Res 2000; 46:269-76.

12. Fabris B, Jackson B, Johnston CI. Salt blocks the renal benefits of ramipril in diabetic hypertensive rats. Hypertension 1991;17:497-503.

13. Buter H, Hemmelder MH, Navis G, et al. The blunting of the antiproteinuric efficacy of ACE inhibition by high sodium intake can be restored by hydrochlorothiazide. Nephrol Dial Transplant 1998;13:1682-5.

14. Biagini G, Zoli M, Torri C, et al. Protective effects of delapril, indapamide and their combination chronically administered to stroke-prone spontaneously hypertensive rats fed a high-sodium diet. Clin Sci 1997;93:401-11.

15. Razzetti R, Bongrani S, Oberto G, et al. Protective effects of delapril, indapamide and their combination on stroke occurrence and lifespan in salt-loaded stroke-prone spontaneously hypertensive rats. Arzneimittelforschung 1998; 48:1083-7.

16. Boschi S, Vantaggiato G, Torri C, et al. Protective effects of delapril combined with indapamide or hydrochlorothiazide in spontaneously hypertensive stroke-prone rats: a comparative dose-response analysis. J Cardiovasc Pharmacol 2000;36:321-8.

17. Yamori $\mathrm{Y}$, Horie R, Tanase $\mathrm{H}$, et al. Possible role of nutritional factors in the incidence of cerebral lesions in stroke-prone spontaneously hypertensive rats. Hypertension 1984;6:49-53.

18. Laschi R, Govoni E. Staining methods for semithin sections. In: Johannessen JV, ed. Electron microscopy in human medicine. vol. 1. Instrumentation and techniques. New York: McGraw-Hill, 1978:187-98.

19. Berg RA. Determination of 3 and 4-hydroxyproline. Methods Enzymol 1982;82:372-98.

20. Venturi M, Bonavina L, Annoni F, et al. Biochemical assays of collagen and elastin in the normal and varicose vein wall. J Surg Res 1996;60:245-8.

21. Contard F, Sabri A, Glukhova M, et al. Arterial smooth muscle cell phenotype in stroke-prone spontaneously hypertensive rats. Hypertension 1993;22:665-76.

22. Richard V, Joannides R, Henry JP, et al. Fixed-dose combination of perindopril with indapamide in spontaneously hypertensive rats: haemodynamic, biologic and structural effects. J Hypertens 1996; 14:1447-54.

23. Benetos A, Levy BI, Lacolley F, et al. Role of angiotensin II and bradykinin on aortic collagen following converting enzyme inhibition in spontaneously hypertensive rats. Arterioscler Thromb Vasc Biol 1997;17:3196-201.

24. Et-Taouil K, Schiavi P, Levy BI, et al. Sodium intake, large artery stiffness, and proteoglycans in the spontaneously hypertensive rat. Hypertension 2001;38:1172-6.

25. Fornieri C, Taparelli F, Quaglino Djr, et al. The effect of caloric restriction on the aortic tissue of aging rats. Connect Tissue Res 1999;40:131-43.

26. SHEP Cooperative Research Group. Prevention of stroke by antihypertensive drug treatment in older persons with isolated systolic hypertension. JAMA 1991;265:3255-64.

27. Lartaud-Idjouadiene I, Lompre AM, Kieffer P, et al. Cardiac consequences of prolonged exposure to an isolated increase in aortic stiffness. Hypertension 1999;34:63-9.

28. Vergely C, Walker MK, Zeller M, et al. Antioxidant properties of indapamide, 5-OH indapamide and hydrochlorothiazide evaluated by oxygen-radical absorbing capacity and electron paramagnetic resonance. Mol Cell Biochem 1998;178:151-5.

29. Zempel G, Ditlevsen J, Hoch M, et al. Effects of indap- 
amide on $\mathrm{Ca}^{2+}$ entry into vascular smooth muscle cells. Nephron 1997;76:460-5.

30. Pickkers P, Hughes AD, Russel FGM, et al. Thiazideinduced vasodilation in humans is mediated by potassium channel activation. Hypertension 1998;32:1071-6.

31. Pickkers P, Garcha RS, Schachter M, et al. Inhibition of carbonic anhydrase accounts for the direct vascular effects of hydrochlorothiazide. Hypertension 1999;33:1043-8.

32. Balla T, Varnai P, Tian Y, et al. Signaling events activated by angiotensin II receptors: what goes before and after the calcium signals. Endocr Res 1998;24:335-44.

33. Contard F, Glukhova M, Marotte F, et al. Diuretic effects on cardiac hypertrophy in the stroke-prone, spontaneously hypertensive rat. Cardiovasc Res 1993;27:429-34.

34. Gosse P, Sheridan DJ, Zannad F, et al. Regression of left ventricular hypertrophy in hypertensive patiens treated with indapamide SR $1.5 \mathrm{mg}$ versus enalapril $20 \mathrm{mg}$ : the LIVE study. J Hypertens 2000;18:1465-75.

35. Levy BI, Poitevin P, Duriez M, et al. Sodium, survival, and the mechanical properties of the carotid artery in strokeprone hypertensive rats. J Hypertens 1997;15:251-8.

36. Feldman R, Bacher M, Campbell N, et al. Adherence to pharmacological management of hypertension. Can J Public Health 1998;89:I16-8. 